\title{
We Sinful Women
}

Kishwar Naheed*

Translated by Rukhsana Ahmed

Address

*Correspondence: [kishwarnaheed72@yahoo.com]

Kishwar Naheed (b. 1940) is one of Pakistan's leading poets, a feminist, and activist in the women's movement. Below is her well-known poem, translated from the original in Urdu.

It is we sinful women

who are not awed by the grandeur of those who wear gowns

who don't sell our lives

who don't bow our heads

who don't fold our hands together.

(C) Copyright: The Authors. This article is issued under the terms of the Creative Commons Attribution NonCommercial Share Alike License, which permits use and redistribution of the work provided that the original author and source are credited, the work is not used for commercial purposes and that any derivative works are made available under the same license terms.

It is we sinful women

while those who sell the harvests of our bodies

become exalted

become distinguished

become the just princes of the material world.

It is we sinful women

who come out raising the banner of truth

up against barricades of lies on the highways

who find stories of persecution piled on each threshold

who find that tongues which could speak have been severed. 
It is we sinful women.

Now, even if the night gives chase

these eyes shall not be put out.

For the wall which has been razed

don't insist now on raising it again.

It is we sinful women

who are not awed by the grandeur of those who wear gowns

who don't sell our bodies

who don't bow our heads

who don't fold our hands together.

Available at: https://urduwallahs.wordpress.com/2016/09/03/we-sinfulwomen/

\section{To cite this article:}

Naheed, K. (2018). We Sinful Women. Feminist Dissent, (3), 192-193.

Retrieved from:

https://iournals.warwick.ac.uk/index.php/feministdissent/index 